\title{
A Comparative Financial Ratio Analysis Between Conventional and Islamic Banks in GCC
}

\author{
Arindam Banerjee \\ Associate Professor, Finance \\ SP Jain School of Global Management, Dubai, United Arab Emirates \\ E-mail: arin_006@yahoo.com
}

Received: November 18, 2021 Accepted: December 18, 2021 Published: December 23, 2021

doi: 10.5296/ijafr.v11i4.19214

URL: https://doi.org/10.5296/ijafr.v11i4.19214

\begin{abstract}
Banking framework establishes the central mainstay of any economy. Banks functions as monetary conduits between sectors that have abundance reserves and those that are in deficiency. The historical backdrop of banking in the Gulf Cooperation Council (GCC) traces all the way back to 1918 with the foundation of the primary bank in Bahrain. The territorial financial evolution is attributable to oil abundance and loaning business that spotlights on building, land and client advances. Throughout the long term, the financial framework worldwide has advanced in its contributions to suit the changing customer requests. One of the essential determinants of this change came about because of the strict convictions of individuals bringing about the remarkable development of Islamic Banking System. The prevalence of these banks are in nations with critical Muslim populace like Iran, Pakistan and Sudan but not limited to them. Islamic banks work under Sharia standards of hazard sharing and premium preclusion as appeared differently in relation to customary banks that purchase cash-flow to pool assets and offer cash-flow to produce revenue pay or benefit. This paper applies banks' endogenic elements identified with their monetary record and pay explanation and utilizing an aggregate of 24 financial ratios relating to the banks' performance and seeks to thoroughly analyze the same among customary and Islamic banks. This examination clarifies the design, activity and the board of traditional banks in the GCC combined with the working of Islamic banks. The paper likewise intends to decide the beneficial and proficient banks among the chosen sample. The study incorporates 20 institutions, similarly dispersed among Islamic and customary banks utilizing information between the time of $2014-2017$. The example is comprehensively ordered dependent on benefit ratios, proficiency ratios, asset indicator ratios and risk ratios. Further sub categorization is done to show up at an aggregate of 24 ratios. An independent T-test is used to determine a substantial ratio between Islamic and conventional banks.
\end{abstract}


JEL classification: G21; F37; P48; P51; N25

Keywords: Islamic banking, Interest-free, Profit-and-loss sharing, Financial Ratios, Bank deposits

\section{Introduction}

Dubai Islamic Bank was the first independent Islamic Bank set up in 1975. Throughout the long term, a few worldwide banks have set up Islamic financial division that maintains customary Islamic qualities and offers items and administrations consistent with Sharia standards. Today, in excess of 200 Islamic banks work in 70 nations with $\$ 2.6$ billion in resources under administration. In its underlying years, Islamic banks saw its development in South Asia and GCC nations. Islamic banks get assets from deposits rather than investors. Rather than the ordinary banks, the rule of risk sharing lead to a superior profit from value for Islamic banks. Factual proof likewise shows that Islamic banks will quite often accomplish a higher net revenue contrasted with customary banks.

\section{Background on Islamic Bank and Conventional Bank}

The contrast between the Islamic Bank and the Conventional Bank is by and large the structure and rule that oversees them. Sharia or Islamic law administers Islamic financial organizations. The sacred book of Islam, Quran disallows all exchanges from getting and paying interest, Riba, as it is accepted that interest bearing credit structure prompts an unjust conveyance of cultural pay. To defeat this test, Islamic banks procures income from benefit sharing arrangements. The idea of premium is rebuilt with a period markup of installments and business financing commissions under the Islamic financial model.

\section{Literature Review}

Tamimi and Amiri (2003) directed exploration on the contrasts between ordinary and Islamic banks among the middle east dependent on financial ratios. Islamic banks principally work on the standards of risk sharing revenue disallowance. However, each bank managed comparative difficulties and in this manner the review couldn't convincingly demonstrate whether financial ratios help can really separate between the two classes of banks. Their research utilized 26 monetary ratios and applied rationale, neural organization and k-means to observe whether scientists and controllers can utilize these ratios in giving explicit contrasts between these two arrangements of banks. Bashier (1983) researched on the administrative consistence among Islamic and Non-Islamic banks in Bangladesh. The review included 223 insights among 23 custom banks and seven Islamic banks between 2003 to 2013. The result of the review guaranteed that Islamic banks having higher income when contrasted with their customary partners were better useful. Grais and Pellegrini (2006) audited corporate administration difficulties of organizations that offered Islamic monetary administrations (IIFS) and proposed choices that tended to them. The paper proposed an unmistakable treatment of corporate Governance issues for IIFS when contrasted with customary corporate administration. The paper proposed an administration model dependent on a blend of inner and outer game plans and that depends intensely on straightforwardness and revelation of data that is market important. Hume (2004) examines the likelihood to recognize traditional 


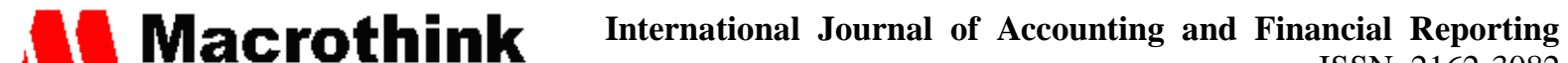 ISSN 2162-3082 2021, Vol. 11, No. 4}

and Islamic banks in the Gulf Cooperation Council (GCC) in view of monetary characteristics. Iqbal (2006) broke down the fluctuated understandings of Riba and the absence of agreement in its importance. The review reasons that Riba in deal credits likewise falls in the classification of genuine Riba and produces results when any of the six items specifically gold, silver, wheat, grain, dates and salt are traded with a delay in various measures, essentially ascribed to the chance of fundamental ware value change making vulnerability for the two players of the trade. Coats and Fant (1993) inspected and broke down the monetary misery forecast utilizing neural organization approach applying monetary proportions. Hassan, Khamis, and Oulidi, (2010) broke down the progressive development of the financial area in the Gulf Cooperation Council (GCC) nations. The review managed cross-line linkages, accounting report openings and dangers, focus, possession, monetary adequacy and late patterns in credit development. The examination recognized the assortment of dangers that represented a danger to the monetary security of the financial area with regards to the worldwide emergency and proposed ways of moderating them. Ajmi, Hussain, and Saleh investigated into the expectations of Bahraini clients in picking a banks, their comprehension of bank items and their relative advantages. Viewed as the principal study on that examples three unmistakable arrangement of customers, specifically Islamic, customary and both. Utilizing poll strategy to 1000 customers and applying Mann-Whitney and Kruskal-Wallis tests and component investigation the review presumed that Islamic strict conviction, social obligation and money saving advantage are the essential determinants in bank choice among Bahraini bank customers. The concentrate likewise uncovered that however the customers of traditional and Islamic banks share normal prerequisites, they truly do vary in their item understandings. Islamic bank customers are more acquainted with sharia 'an agreeable the items/administrations. Islam (2003) investigated the inside exhibition of homegrown and foreign banks in Bahrain, Oman, the United Arab Emirates (GCC nations) by concentrating on their financial ratios. The review showed that the business banks in these nations are all around equipped through the reception of present day banking administrations, they have worked on their exhibition in the beyond couple of years. Most banks were monetarily strong according to global principles and monetary proportions benchmarks. Essayyad and Madani (2003) examined the focus, proficiency, and productivity of business banks in Saudi Arabia. Applying the methods of relapse examination, the creators explored the determinants of Saudi bank proficiency, fixation, and productivity. The significance of the review originated from the hypothesis that profoundly thought banking or credit market got failures that might conceivably impede the bank's admittance to credit driving dialing back development. Kunt and Hizinga (1999) utilizing information for 80 nations crossing a period between 1988-1995 showed that distinctions in revenue bank productivity and edges mirrored a few determinants specifically bank macroeconomic conditions, in general monetary design, unequivocal and understood bank tax collection, store protection guideline, and numerous administrative and institutional pointers. The consequences of the paper showed that a more prominent bank resource for GDP proportion and a lower market fixation proportion lead to bring down edges and benefits. Hussain, Islam, Gunasekaran and Maskooki (2002) brought up that of late, economies and monetary organizations in the GCC nations tried to make nearer ties. This calls for better coordination of bookkeeping guidelines 


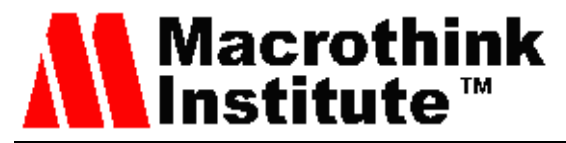

International Journal of Accounting and Financial Reporting

ISSN 2162-3082

bringing about further developed participation and work on the productivity of the monetary establishments among these nations. Muharrami and Matthews (2009) assessed the exhibition of the GCC banking industry in the appearance of the "Design Conduct-Performance" speculation utilizing test information between the time of 1993-2002 and applied board assessment recognizing bank fixed impacts and nation fixed impacts. The paper analyzed the "Relative-Market-Power and the Efficient-Structure theories" recognizing the two by applying a non-parametric proportion of specialized effectiveness, and observed that the financial business in the GCC nations is best clarified by the standard SCP speculation. Regardless of minor contrasts, the GCC share a typical monetary, social and political comparability with a productive, steady and beneficial aggregate financial framework (Al-Muharrami and Matthews 2009). The financial areas add to GDP is close to oil and gas area. This area developed quickly during the period 2000-2008 basically from oil trades. The Islamic banking and monetary administrations industry has shown fast development in the course of recent years, arriving at an achievement of more than $\$ 2$ trillion in esteem by 2015 . GCC banks have developed further, very much promoted and present day banking administrations have been embraced. Islamic banks represented $18 \%$ of the monetary framework in 2007 that represented around $36 \%$ of worldwide Islamic monetary resources. In the course of the last decade, Islamic Banks has developed at a pace of 20 - 30 percent each year, which is multiple times higher than ordinary banks. The Islamic financial framework in examination with customary banks was less impacted by the monetary and monetary emergency since interests in harmful resources and subordinates are completely disallowed (Iqbal, 1997).

\section{Hypotheses to Examine}

To inspect our examination targets, we must have to analyze monetary proportions of ordinary and Islamic banks. For these reasons we have characterized the accompanying exploration speculation.

Hypotheses 1: There is no huge distinction between productivity proportions of ordinary banks and Islamic banks in the UAE.

Hypothesis 2: There is no huge distinction between proficiency proportions of the ordinary banks and Islamic banks in the UAE.

Hypothesis 3: There is no huge distinction between resource nature of the regular banks and Islamic banks in the UAE.

Hypothesis 4: There is no huge distinction between Liquidity of the regular and Islamic banks in the UAE Hypothesis

Hypothesis 5: There is no critical contrast between liquidity hazard the executives of the traditional and Islamic banks in the UAE.

The elective speculation for all the above would remember a huge contrast for the monetary proportions being tried at each stage. 


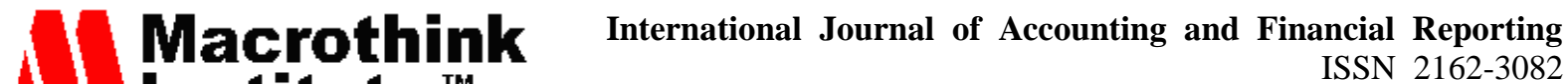 2021, Vol. 11, No. 4}

\section{Data and Methodology}

The proposed study will scientific in nature and will utilize optional information from the yearly distributed fiscal reports of the ordinary and Islamic banks in the UAE. The creators have picked quantitative investigation utilizing dominate to come to the end result. Information identifying with productivity, effectiveness, resource quality, liquidity and hazard the executives have been taken from the yearly reports of 2018. The example size comprises of top 5 regular banks and Islamic banks, individually, working in the UAE. These include:

Conventional banks:
i. First Abu Dhabi Bank (FAB),
ii. Emirates NBD (ENBD),
iii. Abu Dhabi Commercial Bank (ADCB),
iv. Mashreq Bank (MB),
v. Commercial Bank Dubai (CBD)

Islamic Banks:

i. Abu Dhabi Islamic Bank (ADIB),

ii. Dubai Islamic Bank (DIB),

iii. Noor Bank (NB) and

iv. Sharjah Islamic Bank (SIB)

v. Al Hilal Bank (AHB)

\subsection{Dependent and Independent Variables}

\begin{tabular}{|c|c|c|c|c|c|}
\hline Ratio & variables & variables & Formula & $\begin{array}{l}\text { Dependent/ } \\
\text { Independent }\end{array}$ & Description \\
\hline $\begin{array}{l}\text { Bank } \\
\text { profitability } \\
\text { ratios }\end{array}$ & ROA & return on assets & $\begin{array}{l}\text { net income/ average } \\
\text { total assets. }\end{array}$ & Dependent & $\begin{array}{l}\text { The return on assets shows the percentage of how } \\
\text { profitable a company's assets are in generating revenue. }\end{array}$ \\
\hline $\begin{array}{l}\text { Bank efficiency } \\
\text { ratios }\end{array}$ & NIM & $\begin{array}{l}\text { net interest } \\
\text { margin }\end{array}$ & $\begin{array}{l}\text { (net interest } \\
\text { income-net interest } \\
\text { expenses) / average } \\
\text { total assets. }\end{array}$ & Dependent & $\begin{array}{l}\text { Net interest margin is a measure of the difference } \\
\text { between the interest income generated by banks or other } \\
\text { financial institutions and the amount of interest paid out } \\
\text { to their lenders, relative to the amount of their assets. }\end{array}$ \\
\hline $\begin{array}{l}\text { Asset-quality } \\
\text { indicators }\end{array}$ & PEA & $\begin{array}{l}\text { provision to } \\
\text { earning assets }\end{array}$ & $\begin{array}{l}\text { provision for loan } \\
\text { losses / average total } \\
\text { loans and advances. }\end{array}$ & Dependent & $\begin{array}{l}\text { A loan loss provision is an expense set aside as an } \\
\text { allowance for uncollected loans and loan payments. } \\
\text { This provision is used to cover a number of factors } \\
\text { associated with potential loan losses, including bad } \\
\text { loans, customer defaults, and renegotiated terms of a } \\
\text { loan that incur lower than previously estimated } \\
\text { payments }\end{array}$ \\
\hline
\end{tabular}




\section{Macrothink}

International Journal of Accounting and Financial Reporting

ISSN 2162-3082

2021, Vol. 11, No. 4

\begin{tabular}{|c|c|c|c|c|c|}
\hline Liquidity ratios & CTA & cash to assets & $\begin{array}{l}\text { cash / average total } \\
\text { assets. }\end{array}$ & Dependent & $\begin{array}{l}\text { A liquid asset requirement, or ratio, is defined as the } \\
\text { obligation of commercial banks to maintain a } \\
\text { predetermined percentage of total deposits and certain } \\
\text { other liabilities in the form of liquid assets. }\end{array}$ \\
\hline Risk ratios & EM & equity multiplier & $\begin{array}{l}\text { average total assets / } \\
\text { average stockholders' } \\
\text { equity. }\end{array}$ & Dependent & $\begin{array}{l}\text { The equity multiplier is a financial leverage ratio that } \\
\text { measures the amount of a bank's assets that are } \\
\text { financed by its shareholders by comparing total assets } \\
\text { with total shareholder's equity. In other words, the } \\
\text { equity multiplier shows the percentage of assets that are } \\
\text { financed or owed by the shareholders. }\end{array}$ \\
\hline $\begin{array}{l}\text { Bank } \\
\text { profitability } \\
\text { ratios }\end{array}$ & ROE & return on equity & $\begin{array}{l}\text { net income/ average } \\
\text { stockholders' equity. }\end{array}$ & Independent & $\begin{array}{l}\text { the return on equity is a measure of the profitability of a } \\
\text { business in relation to the equity, also known as net } \\
\text { assets or assets minus liabilities. ROE is a measure of } \\
\text { how well a company uses investments to generate } \\
\text { earnings growth }\end{array}$ \\
\hline $\begin{array}{l}\text { Bank } \\
\text { profitability } \\
\text { ratios }\end{array}$ & $\mathrm{PM}$ & profit margin & $\begin{array}{l}\text { net income/ operating } \\
\text { income. }\end{array}$ & Independent & $\begin{array}{l}\text { Profit margin, net margin, net profit margin or net profit } \\
\text { ratio is a measure of profitability. It is calculated by } \\
\text { finding the net profit as a percentage of the revenue. }\end{array}$ \\
\hline $\begin{array}{l}\text { Bank } \\
\text { profitability } \\
\text { ratios }\end{array}$ & ROD & $\begin{array}{l}\text { return on } \\
\text { deposits }\end{array}$ & $\begin{array}{l}\text { net income/ average } \\
\text { total customer } \\
\text { deposits. }\end{array}$ & Independent & $\begin{array}{l}\text { It is calculated by dividing net income to average total } \\
\text { customer deposits }\end{array}$ \\
\hline $\begin{array}{l}\text { Bank } \\
\text { profitability } \\
\text { ratios }\end{array}$ & ROSC & $\begin{array}{l}\text { return on } \\
\text { shareholder } \\
\text { capital }\end{array}$ & $\begin{array}{l}\text { net income/ } \\
\text { shareholder } \\
\text { contributed capital. }\end{array}$ & Independent & $\begin{array}{l}\text { Return on shareholder equity is a measure of financial } \\
\text { performance calculated by dividing net income by } \\
\text { shareholders' equity. Because shareholders' equity is } \\
\text { equal to a company's assets minus its debt, ROE could } \\
\text { be thought of as the return on net assets }\end{array}$ \\
\hline $\begin{array}{l}\text { Bank } \\
\text { profitability } \\
\text { ratios }\end{array}$ & NOM & $\begin{array}{l}\text { net operating } \\
\text { margin }\end{array}$ & $\begin{array}{l}\text { operating profit or } \\
\text { income/ interest } \\
\text { income. }\end{array}$ & Independent & $\begin{array}{l}\text { The net interest margin in banking is similar to the gross } \\
\text { profit margin for operating companies. It is equal to a } \\
\text { bank's total interest income minus total interest expense }\end{array}$ \\
\hline $\begin{array}{l}\text { Bank efficiency } \\
\text { ratios }\end{array}$ & IEE & $\begin{array}{l}\text { interest income } \\
\text { to expenses }\end{array}$ & $\begin{array}{l}\text { (interest } \\
\text { income-interest } \\
\text { expenses) / average } \\
\text { total loans and } \\
\text { advances. }\end{array}$ & Independent & $\begin{array}{l}\text { It is calculated by dividing NIM to average total loans } \\
\text { and advances }\end{array}$ \\
\hline $\begin{array}{l}\text { Bank efficiency } \\
\text { ratios }\end{array}$ & OEA & $\begin{array}{l}\text { operating } \\
\text { expense to assets }\end{array}$ & $\begin{array}{l}\text { operating expenses/ } \\
\text { average total assets. }\end{array}$ & Independent & $\begin{array}{l}\text { It is calculated by dividing operating expenses to } \\
\text { average total assets }\end{array}$ \\
\hline $\begin{array}{l}\text { Bank efficiency } \\
\text { ratios }\end{array}$ & OIA & $\begin{array}{l}\text { operating } \\
\text { income to assets }\end{array}$ & $\begin{array}{l}\text { operating income/ } \\
\text { average total assets. }\end{array}$ & Independent & $\begin{array}{l}\text { It is calculated by dividing operating income to average } \\
\text { total assets }\end{array}$ \\
\hline $\begin{array}{l}\text { Bank efficiency } \\
\text { ratios }\end{array}$ & OER & $\begin{array}{l}\text { operating } \\
\text { expenses to } \\
\text { revenue }\end{array}$ & $\begin{array}{l}\text { operating expenses/ } \\
\text { operating income } \\
\text { (revenue). }\end{array}$ & Independent & $\begin{array}{l}\text { Expense to income ratio is calculated by dividing the } \\
\text { operating expenses by the operating income generated } \\
\text { i.e.net interest income plus the other income. } \\
\text { Cost-to-income ratio is important for determining the } \\
\text { profitability of a bank }\end{array}$ \\
\hline
\end{tabular}




\section{Il Macrothink}

International Journal of Accounting and Financial Reporting

ISSN 2162-3082

2021, Vol. 11, No. 4

\begin{tabular}{|c|c|c|c|c|c|}
\hline $\begin{array}{l}\text { Bank efficiency } \\
\text { ratios }\end{array}$ & ATO & asset turnover & $\begin{array}{l}\text { interest income/ } \\
\text { average total assets. }\end{array}$ & Independent & $\begin{array}{l}\text { Asset Turnover measures how quickly a company turns } \\
\text { over its asset through sales. It is calculated as Revenue } \\
\text { divided by Total Assets }\end{array}$ \\
\hline $\begin{array}{l}\text { Bank efficiency } \\
\text { ratios }\end{array}$ & NNIM & $\begin{array}{l}\text { net non-interest } \\
\text { margin }\end{array}$ & $\begin{array}{l}\text { (net non-interest } \\
\text { income-net } \\
\text { non-interest expenses) } \\
\text { /average total assets. }\end{array}$ & Independent & $\begin{array}{l}\text { No interest margin is a financial measurement that helps } \\
\text { asses the usefulness of revenue from non-interest items } \\
\text { such as fees and service charges. }\end{array}$ \\
\hline $\begin{array}{l}\text { Asset-quality } \\
\text { indicators }\end{array}$ & LR & loan ratio & $\begin{array}{l}\text { average total loans and } \\
\text { advances / average } \\
\text { total assets. }\end{array}$ & Independent & $\begin{array}{l}\text { It is calculated by dividing Average total loans to } \\
\text { average total assets }\end{array}$ \\
\hline $\begin{array}{l}\text { Asset-quality } \\
\text { indicators }\end{array}$ & LTD & loans to deposits & $\begin{array}{l}\text { average total loans and } \\
\text { advances / average } \\
\text { total customer } \\
\text { deposits. }\end{array}$ & Independent & $\begin{array}{l}\text { The loan-to-deposit ratio (LDR) is used to assess a } \\
\text { bank's liquidity by comparing a bank's total loans to its } \\
\text { total deposits for the same period. }\end{array}$ \\
\hline Liquidity ratios & CTD & cash to deposits & $\begin{array}{l}\text { cash / average total } \\
\text { customer deposits. }\end{array}$ & Independent & $\begin{array}{l}\text { Cash Deposit ratio (CDR) is the ratio of how much a } \\
\text { bank lends out of the deposits it has mobilized. It } \\
\text { indicates how much of a bank's core funds are being } \\
\text { used for lending, the main banking activity }\end{array}$ \\
\hline Risk ratios & DTA & deposits to assets & $\begin{array}{l}\text { average total customer } \\
\text { deposits / average total } \\
\text { assets. }\end{array}$ & Independent & $\begin{array}{l}\text { Deposits to Assets is a ratio that tells you that to what } \\
\text { extent bank's assets have been funded from a stable } \\
\text { source }\end{array}$ \\
\hline Risk ratios & ETD & $\begin{array}{l}\text { equity to } \\
\text { deposits }\end{array}$ & $\begin{array}{l}\text { average shareholders' } \\
\text { equity / average } \\
\text { customer total } \\
\text { deposits. }\end{array}$ & Independent & $\begin{array}{l}\text { It is calculated by dividing average shareholders' equity } \\
\text { to average customer total deposits. }\end{array}$ \\
\hline Risk ratios & TLE & $\begin{array}{l}\text { total liabilities to } \\
\text { equity }\end{array}$ & $\begin{array}{l}\text { average total liabilities } \\
\text { / average stockholders' } \\
\text { equity. }\end{array}$ & Independent & $\begin{array}{l}\text { The Debt to Equity ratio is calculated as total liabilities } \\
\text { divided by total shareholders' equity }\end{array}$ \\
\hline Risk ratios & TLSC & $\begin{array}{l}\text { total liabilities to } \\
\text { shareholder } \\
\text { capital }\end{array}$ & $\begin{array}{l}\text { average total liabilities } \\
\text { / shareholder } \\
\text { contributed capital. }\end{array}$ & Independent & $\begin{array}{l}\text { It is calculated by dividing Average total loans to } \\
\text { average total assets }\end{array}$ \\
\hline Risk ratios & RETA & $\begin{array}{l}\text { retained } \\
\text { earnings to total } \\
\text { assets }\end{array}$ & $\begin{array}{l}\text { retained earnings / } \\
\text { average total assets." }\end{array}$ & Independent & $\begin{array}{l}\text { The retained earnings to total assets ratio measures the } \\
\text { banks' ability to accumulate earnings using its assets }\end{array}$ \\
\hline
\end{tabular}

\subsection{Descriptive Analysis}

The study is proposed to include regression analysis to ascertain underlying factors that contribute to the performance of conventional and Islamic banks in the UAE. Based on the formation of hypothesis, five different models have been established. These models will encompass one independent variable and several dependent variables within each hypothesis. This has been described in Table 1 below. Mehta, A., \& Bhavani, G. (2017) stated that there are several internal and external variables that are determinants of the profitability of the profitability of the banks in the UAE. Most notable among these were the cost efficiency ratio, 


\section{NI Macrothink}

International Journal of Accounting and Financial Reporting

ISSN 2162-3082

2021, Vol. 11, No. 4

adequate capital adequacy ratio and improvement in the asset quality ratio. However, it is also important to keep in mind Return on Assets which could also enhance profitability by diversifying income sources.

Table 1. Descriptive statistics for conventional and Islamic banks based on defined hypothesis

\begin{tabular}{|c|c|c|c|c|c|c|c|c|c|c|c|}
\hline \multirow[b]{2}{*}{ variables } & \multirow{2}{*}{$\begin{array}{l}\text { Dependent/ } \\
\text { Independent } \\
\text { variables }\end{array}$} & \multicolumn{5}{|c|}{ Conventional Banks } & \multicolumn{5}{|c|}{ Islamic Banks } \\
\hline & & $\begin{array}{c}\text { Sample } \\
\text { Size }\end{array}$ & $\begin{array}{l}\text { Min } \\
\text { value }\end{array}$ & $\begin{array}{l}\text { Max } \\
\text { value }\end{array}$ & Mean & $\begin{array}{l}\text { Standard } \\
\text { Deviation }\end{array}$ & $\begin{array}{c}\text { Sample } \\
\text { Size }\end{array}$ & $\begin{array}{l}\text { Min } \\
\text { value }\end{array}$ & $\begin{array}{l}\text { Max } \\
\text { value }\end{array}$ & Mean & $\begin{array}{l}\text { Standard } \\
\text { Deviation }\end{array}$ \\
\hline $\begin{array}{l}\text { Return on } \\
\text { Assets (ROA) }\end{array}$ & Dependent & 6 & 0.0148 & 0.0201 & 0.0169 & 0.0018 & 6 & 0.0024 & 0.0224 & 0.0140 & 0.0071 \\
\hline $\begin{array}{l}\text { Net Interest } \\
\text { Margin (NIM) }\end{array}$ & Dependent & 6 & 0.0175 & 0.0526 & 0.0289 & 0.0121 & 6 & 0.0134 & 0.0350 & 0.0250 & 0.0072 \\
\hline $\begin{array}{l}\text { Provision to } \\
\text { Earning Assets } \\
\text { (PEA) }\end{array}$ & Dependent & 6 & 0.0048 & 0.0425 & 0.0151 & 0.0143 & 6 & 0.0019 & 0.0189 & 0.0094 & 0.0061 \\
\hline $\begin{array}{l}\text { Cash to Assets } \\
\text { (CA) }\end{array}$ & Dependent & 6 & 0.1303 & 0.3084 & 0.2139 & 0.0732 & 6 & 0.1379 & 0.3156 & 0.2140 & 0.0588 \\
\hline $\begin{array}{l}\text { Equity } \\
\text { Multiplier (EM) }\end{array}$ & Dependent & 6 & 6.7386 & 8.5300 & 7.6342 & 0.6286 & 6 & 6.5545 & 8.4380 & 7.7338 & 0.7546 \\
\hline $\begin{array}{l}\text { Return On } \\
\text { Equity (ROE) }\end{array}$ & Independent & 6 & 0.0995 & 0.1568 & 0.1295 & 0.0206 & 6 & 0.0193 & 0.1466 & 0.1050 & 0.0470 \\
\hline $\begin{array}{l}\text { Profit Margin } \\
(\mathrm{PM})\end{array}$ & Independent & 6 & 0.2398 & 0.6205 & 0.4556 & 0.1449 & 6 & 0.0842 & 0.6101 & 0.3753 & 0.1742 \\
\hline $\begin{array}{l}\text { Return On } \\
\text { Deposits (ROD) }\end{array}$ & Independent & 6 & 0.0219 & 0.0289 & 0.0260 & 0.0024 & 6 & 0.0034 & 0.0321 & 0.0198 & 0.0096 \\
\hline $\begin{array}{l}\text { Return on } \\
\text { Shareholder } \\
\text { Capital (ROSC) }\end{array}$ & Independent & 6 & 0.0995 & 0.1568 & 0.1295 & 0.0206 & 6 & 0.0193 & 0.1466 & 0.1050 & 0.0470 \\
\hline $\begin{array}{l}\text { Net Operating } \\
\text { Margin (NOM) }\end{array}$ & Independent & 6 & 0.7929 & 1.1074 & 0.9373 & 0.1075 & 6 & 0.7347 & 1.1314 & 0.9551 & 0.1579 \\
\hline $\begin{array}{l}\text { Interest Income } \\
\text { to Expenses } \\
\text { (IIE) }\end{array}$ & Independent & 6 & 0.0369 & 0.0843 & 0.0490 & 0.0182 & 6 & 0.0248 & 0.0557 & 0.0401 & 0.0105 \\
\hline $\begin{array}{l}\text { Operating } \\
\text { Expense to } \\
\text { Assets (OEA) }\end{array}$ & Independent & 6 & 0.0068 & 0.0282 & 0.0146 & 0.0077 & 6 & 0.0104 & 0.0211 & 0.0160 & 0.0040 \\
\hline $\begin{array}{l}\text { Operating } \\
\text { Income to } \\
\text { Assets (OIA) }\end{array}$ & Independent & 6 & 0.0261 & 0.0727 & 0.0410 & 0.0164 & 6 & 0.0260 & 0.0461 & 0.0363 & 0.0077 \\
\hline $\begin{array}{l}\text { Operating } \\
\text { Expenses to } \\
\text { Revenue (OER) }\end{array}$ & Independent & 6 & 0.2589 & 0.4409 & 0.3432 & 0.0634 & 6 & 0.2831 & 0.5740 & 0.4477 & 0.1054 \\
\hline
\end{tabular}




\begin{tabular}{|c|c|c|c|c|c|c|c|c|c|c|c|}
\hline $\begin{array}{l}\text { Asset Turnover } \\
\text { (AT) }\end{array}$ & Independent & 6 & 0.0294 & 0.0656 & 0.0429 & 0.0121 & 6 & 0.0296 & 0.0424 & 0.0380 & 0.0045 \\
\hline $\begin{array}{l}\text { Net } \\
\text { Non-Interest } \\
\text { Margin (NNIM) }\end{array}$ & Independent & 6 & $\begin{array}{c}-0.008 \\
1\end{array}$ & 0.0019 & -0.0027 & 0.0033 & 6 & $\begin{array}{c}-0.010 \\
6\end{array}$ & 0.0097 & -0.0032 & 0.0075 \\
\hline Loan Ratio (LR) & Independent & 6 & 0.4745 & 0.6875 & 0.5886 & 0.0862 & 6 & 0.5391 & 0.6526 & 0.6190 & 0.0408 \\
\hline $\begin{array}{l}\text { Loans to } \\
\text { Deposits (LD) }\end{array}$ & Independent & 6 & 0.7842 & 1.0201 & 0.9496 & 0.0979 & 6 & 0.8123 & 0.9787 & 0.9304 & 0.0633 \\
\hline $\begin{array}{l}\text { Cash to } \\
\text { Deposits (CD) }\end{array}$ & Independent & 6 & 0.1816 & 0.5186 & 0.3331 & 0.1288 & 6 & 0.1981 & 0.4428 & 0.3071 & 0.0887 \\
\hline $\begin{array}{l}\text { Deposits to } \\
\text { Assets (DA) }\end{array}$ & Independent & 6 & 0.5947 & 0.7175 & 0.6521 & 0.0460 & 6 & 0.5909 & 0.8020 & 0.7027 & 0.0675 \\
\hline $\begin{array}{l}\text { Equity to } \\
\text { Deposits (ED) }\end{array}$ & Independent & 6 & 0.1734 & 0.2495 & 0.2034 & 0.0283 & 6 & 0.1700 & 0.2192 & 0.1864 & 0.0202 \\
\hline $\begin{array}{l}\text { Total Liabilities } \\
\text { to Equity (TLE) }\end{array}$ & Independent & 6 & 5.7386 & 7.5300 & 6.6342 & 0.6286 & 6 & 5.5545 & 7.4380 & 6.7338 & 0.7546 \\
\hline $\begin{array}{l}\text { Total Liabilities } \\
\text { to Shareholder } \\
\text { Capital (TLSC) }\end{array}$ & Independent & 6 & 5.9157 & 8.5756 & 7.1698 & 0.9821 & 6 & 7.0957 & 10.4447 & 8.0712 & 1.2380 \\
\hline $\begin{array}{l}\text { Retained } \\
\text { Earnings to } \\
\text { Total Assets } \\
\text { (RETA) }\end{array}$ & Independent & 6 & 0.0369 & 0.1336 & 0.0865 & 0.0322 & 6 & - & 0.0870 & 0.0439 & 0.0368 \\
\hline
\end{tabular}

For the reliant factors, the creator has picked ROA, NIM, PEA, CA and EM. The reliant factors relate to studies made by Pradhan, R. S., and Shrestha, R. (2016) which expressed that administration productivity has a positive solid connection to the bank execution. While full scale monetary elements are significant, they don't assume a fundamental part on the effect of the exhibition of the bank. The concentrate additionally uncovered that ROA and NIM could be unequivocal elements influencing banks execution. Menicucci, E., and Paolucci, G. (2016) further explored the connection between bank explicit elements with benefit in the European Banking Sector to discover the job of inside factors accomplishing higher productivity. His investigation utilized relapse model for 35 banks dependent on capital proportions and advance misfortune arrangement proportions on the proficiency of the banks over the period 2009 to 2013. His review proposed that manages an account with higher stores and credit proportions are more productive yet their impact was genuinely immaterial to think about proficiency of these banks. Abobaker, M. J. (2018) concentrate on expressed that high benefit can be accomplished by expanding the bank resources, capital proportion and working pay. Subsequently, the productivity is diminished as non-interest pay increments over the long run. Following similar ideas for regular and Islamic banks as given in Table 1 above, there is ostensible deviation in ROA, NIM and CA of the customary and Islamic banks in the UAE. The explanation could remember that banks for UAE apply comparative loan costs and include adequate fluid resources inside UAE disregarding full scale monetary variables. There is huge 
variety in PEA and the explanation could be the shariah prerequisites which should be trailed by the Islamic banks as these are more moderate in their loaning rehearses. For free factors, the table uncovers scope of variety. Most prominent variety is found in ROE, ED, TLSC and RETA. The justification for huge distinction in the means is because of size and piece of the bank's asset report. Likewise, a few banks have been in presence for a more extended time frame than others viz customary banks in the UAE. While other free factors show immaterial variety, it connotes consistency of the plan of action among Islamic and regular banks. It must be realized that UAE is an overbanked market with 22 neighborhood public banks, 27 parts of unfamiliar banks and 11 discount unfamiliar bank offices as at 30 June 2019. Further, despite the fact that there is interest for Islamic items, UAE Islamic banks partake in a generally little piece of the pie when contrasted with its customary partners as expressed by study directed by Manoj, K (2020).

\section{Accounting Ratios}

accounting Ratios Across the GCC, regular banks have embraced bookkeeping approaches dependent on International Accounting Standards Board (IASB) (Hussain, Islam, Gunasekaran and Maskooki 2002). Interestingly, Islamic banks follow bookkeeping arrangements set up by the Accounting and Auditing Organization for Islamic Financial Institutions (AAOFI). Each Islamic bank builds up a Sharia board that screens and analyzes all bank exchanges in consistence with Islamic standards. The 24 monetary proportions utilized in the exploration are characterized in annexure 1. They are ordered dependent on benefit, effectiveness, nature of resources and hazard. Existing exploration zeroed in exclusively on benefit and proficiency. This exploration utilizes proportions like Bank Return on Asset (ROA), Profit Margin (PM), Deposit Return (ROA), Equity Return (ROE) and Return on Shareholder Capital (ROSC). In light of the past study, Hypotheses 2 expresses that Islamic banks are more moneymaking than ordinary banks. Arrangement for procuring benefit (PEA), show how a bank deals with its resources. High PEA infers higher stores for awful advances and unanticipated crises and to bring down hazard

\section{Descriptive Statistics}

The research begins by examining the possibility of distinguishing between conventional banks and Islamic banks using financial data. Table 1 shows descriptive statistics of both categories. Results of table 1 (sig 2 tail) shows the result of the t-test for equity of means between the two bank categories for each of 24 ratios. In total, only 2 ratios have mean values that differ significantly at the confidence level of 10 percent between the two categories of banks. Accepting Hypotheses 1, the two types of banks can therefore be distinguished primarily by two ratios, NIMM and LR. This is mainly due to the nature of the interest ban on Islamic banks. This has led to changes in non - interest earnings and loan ratios.

Rejecting Hypotheses 2 - Islamic banks are not significantly profitable as the means of profitability ratio shown in Table 1 , due to the remodeling of Islamic banks.

Rejecting Hypotheses 3 - the efficiency ratio also shows that between the two types of banks there is no significant difference in efficiency. The results imply that each category of bank 


\section{MlMacrothink}

International Journal of Accounting and Financial Reporting

ISSN 2162-3082

2021, Vol. 11, No. 4

characteristically has the same efficiency when measured on common grounds; however, Islamic banks are more efficient than conventional banks on average when measured against their own borders. This is again due to the standardized restructuring of the bank operations of Islamic banks and conventional banks.

\section{Summary and Conclusion}

This paper examines the comparative performance between conventional and Islamic banks in GCC countries. The GCC financial environment has a number of standard monetary procedures in the GCC countries. The study uses several statistical tools to ensure their reliability, including mean testing and T-testing. Results from the study reveals indicators of financial characteristics such as profitability ratios, efficiency ratios, asset quality indicators and cash/liability ratios. Results show that Islamic banks are operationally efficient and profitable because of risks sharing and greater dependency on deposits capital. The results also show that operating efficiency and profitability are not significantly different. Economic conditions in the GCC have shielded the exposure of Islamic banks to risks.

\section{References}

Abobaker, M. J. (2018). Bank specific, industry concentration and macroeconomic determinants of Egyptian bank profitability. International Journal of Accounting and Financial Studies, 8(1), 380-397.

Ahmed Abdel Karim, Rifaat, \& El-Tigani Ali, Amal. (2006). Determinants of the Financial Strategy of Islamic Banks. Journal of Business Finance \& Accounting, 16, 193-212. https://doi.org/10.1111/j.1468-5957.1989.tb00013. x

Ajmi, J., Hussain, H. A., \& Al-Saleh, N. (2009). Clients of conventional and Islamic banks in Bahrain: How they choose which bank to patronize. International Journal of Social Economics, 36(11), 1086-1112.

Al-Hassan, A., Khamis, M., \& Oulidi, N. (2010). The GCC banking sector: Topography and analysis. Banks and Banks Systems, 5(3), 15-28.

Al-Muharrami, S., \& Matthews, K. (2009). Market power versus efficient-structure in Arab GCC banking. Working paper No.7, Cardiff business school.

Al-Tamimi, H. A., \& Al-Amiri, A. (2003). Analyzing service quality in the UAE Islamic banks. Journal of Financial Services Marketing, 8(2), 119-132.

Bashier, B. A. (1983). Portfolio management of Islamic banks: A certainty approach. Journal of Banking and Finance, 7(3), 339-354.

Coats, P., \& Fant, L. (1993). Recognizing financial distress patterns using a neural network tool. Financial Management, 22(3), 142-155.

Demirgue-Kunt, A., \& Hizinga, H. (1999). Determinants of commercial bank interest margins and profitability: Some international evidence. The World Bank Economic Review, 13(2), 379-408. 


\section{Ml Macrothink}

International Journal of Accounting and Financial Reporting ISSN 2162-3082 2021, Vol. 11, No. 4

Essayyad, M., \& Madani, H. (2003). Investigating bank structure of an open petroleum economy: The case of Saudi Arabia. Managerial Finance, 29(11), 73-92.

Grais, W., \& Pellegrini, M. (2006). Corporate governance and Sharia compliance in institutions offering Islamic financial services. World Bank policy working paper: 4054, November, 2006 (pp. 1-34).

Hume, J. (2004). Islamic finance: Provenance and prospects. International Financial Law Review, 23(5), 1-4.

Hussain, M., Islam, M., Gunasekaran, A., \& Maskooki, K. (2002). Accounting standards and practices of financial institutions in GCC countries. Managerial Auditing Journal, 17(7), $350-362$.

Iqbal, M. (2006). A broader definition of Riba: Pakistan Institute of Development Economics working paper. Institute of Islamic Banking and Insurance, 2005.

Islam, M. (2003). Development and performance of domestic and foreign banks in the GCC countries.

Mehta, A., \& Bhavani, G. (2017). What determines banks' profitability? evidence from emerging markets-the case of the UAE ban king sector. Accounting and Finance Research, 6(1), 77-88.

Menicucci, E., \& Paolucci, G. (2016). The determinants of bank profitability: empirical evidence from European banking sector. Journal of Financial Reporting and Accounting.

Pradhan, R. S., \& Shrestha, R. (2016). Impact of Bank Specific and Macroeconomic Variables on the Performance of Commercial Banks of Nepal. Available at SSRN 2793530

Saiful Azhar Rosly, \& Mohd Afandi Abu Bakar. (2003). Performance of Islamic and mainstream banks in Malaysia. International Journal of Social Economics, 30(12), 1249-1265, https://doi.org/10.1108/03068290310500652

\section{Annexure 1}

\section{Bank profitability ratios}

$\mathrm{ROA}=$ return on assets $=\mathrm{NI} / \mathrm{ATA}=$ net income $/$ average total assets.

$\mathrm{ROE}=$ return on equity $=\mathrm{NI} / \mathrm{SE}=$ net income/ average stockholders' equity.

$\mathrm{PM}=$ profit $\operatorname{margin}=\mathrm{NI} / \mathrm{OI}=$ net income/ operating income.

$\mathrm{ROD}=$ return on deposits=NI /ATD=net income/ average total customer deposits.

$\mathrm{ROSC}=$ return on shareholder capital=NI $/ \mathrm{SC}=$ net income/ shareholder contributed capital.

$\mathrm{NOM}=$ net operating margin=OI /IN=operating profit or income/ interest income.

\section{Bank efficiency ratios}

IEE=interest income to expenses $=(\mathrm{IN}-\mathrm{IE}) / \mathrm{ATLA}=$ (interest income-interest expenses $) /$ average total_loans and advances. 
$\mathrm{OEA}=$ operating expense to assets=OE/ATA=operating expenses/ average total assets. $\mathrm{OIA}=$ operating income to assets $=\mathrm{OI} / \mathrm{ATA}=$ operating income/ average total assets.

$\mathrm{OER}=$ operating expenses to revenue $=\mathrm{OE} / \mathrm{OI}=$ operating expenses/ operating income (revenue).

$\mathrm{ATO}=$ asset turnover=IN/ATA=interest income/ average total assets.

$\mathrm{NIM}=$ net interest margin $=(\mathrm{IN}-\mathrm{IE}) / \mathrm{ATA}=($ net interest income - net interest expenses $) /$ average total assets.

$\mathrm{NNIM}=$ net non-interest $\operatorname{margin}=(\mathrm{NIN}-\mathrm{NIE}) / \mathrm{ATA}=($ net non-interest income - net non-interest expenses) /average total assets.

\section{Asset-quality indicators}

$\mathrm{PEA}=$ provision to earning assets=PLL/ATLA=provision for loan losses / average total loans and advances.

$\mathrm{LR}=$ loan ratio=ATLA/ATA $=$ average total loans and advances $/$ average total assets.

$\mathrm{LTD}=$ loans to deposits=ATLA/ATD=average total loans and advances / average total customer deposits.

\section{Liquidity ratios}

$\mathrm{CTA}=$ cash to assets $=\mathrm{C} / \mathrm{ATA}=$ cash $/$ average total assets.

$\mathrm{CTD}=$ cash to deposits $=\mathrm{C} / \mathrm{ATD}=$ cash $/$ average total customer deposits.

\section{Risk ratios}

DTA=deposits to assets=ATD/ATA=average total customer deposits / average total assets. $\mathrm{EM}=$ equity multiplier=ATA/SE=average total assets / average stockholders' equity.

$\mathrm{ETD}=$ equity to deposits=SE/ATD=average shareholders' equity / average customer total deposits.

TLE=total liabilities to equity=TL/SE=average total liabilities / average stockholders' equity.

TLSC=total liabilities to shareholder capital=TL/SC=average total liabilities $/$ shareholder contributed capital.

RETA=retained earnings to total assets=RE/ATA=retained earnings / average total assets." 


\section{Descriptive statistics}

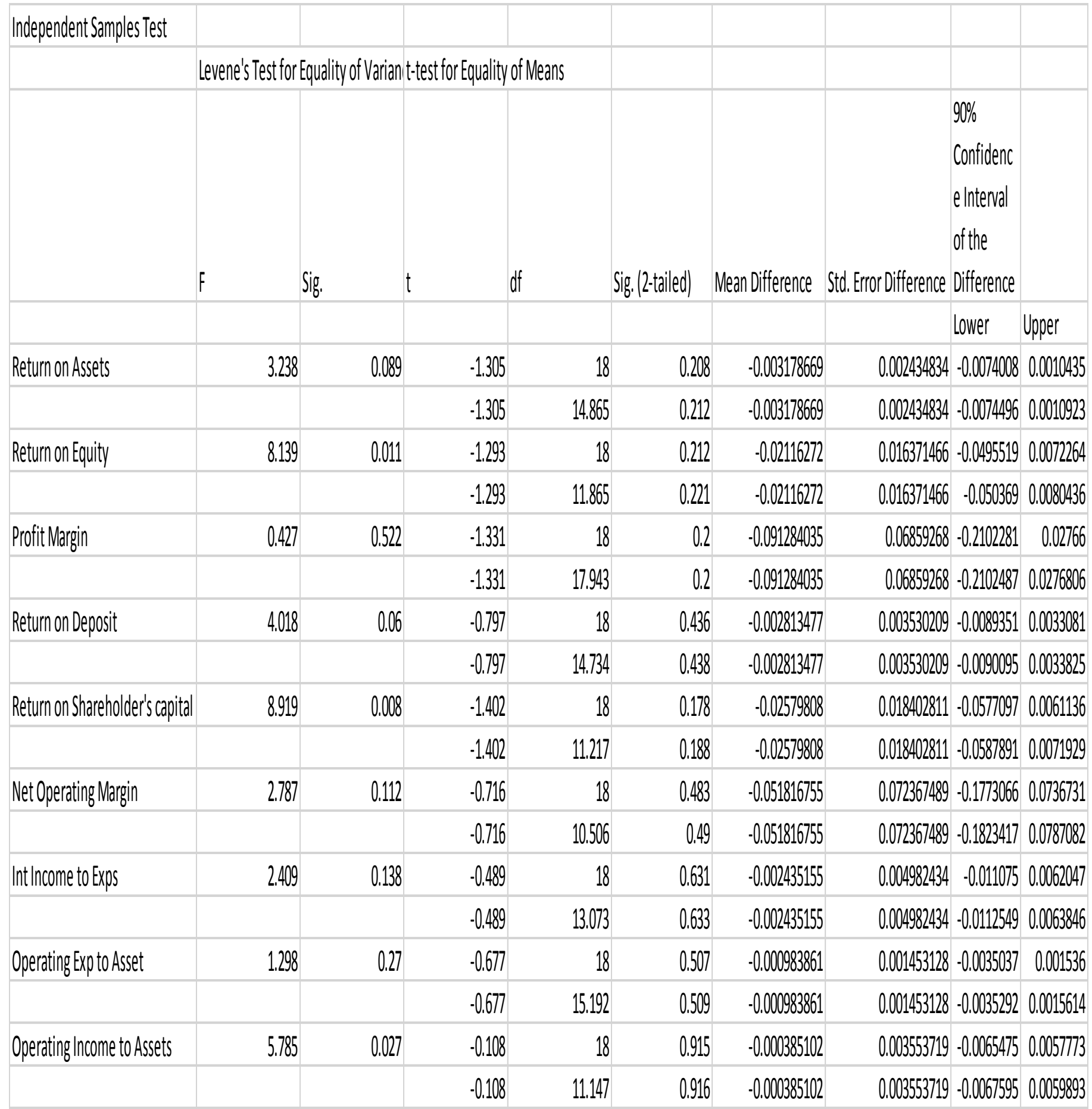




\begin{tabular}{|c|c|c|c|c|c|c|c|}
\hline \multirow[t]{2}{*}{ Operating Exps to Revenue } & 2.525 & 0.129 & 0.512 & 18 & 0.615 & 0.045588759 & $0.088954684-0.10866430 .1998418$ \\
\hline & & & 0.512 & 9.977 & 0.619 & 0.045588759 & $0.088954684-0.11567580 .2068533$ \\
\hline \multirow[t]{2}{*}{ Asset Turnover } & 5.785 & 0.027 & -0.108 & 18 & 0.915 & -0.000385102 & $0.003553719-0.00654750 .0057773$ \\
\hline & & & -0.108 & 11.147 & 0.916 & -0.000385102 & $0.003553719-0.00675950 .0059893$ \\
\hline \multirow[t]{2}{*}{ Net Int Margin } & 5.9 & 0.026 & 0.03 & 18 & 0.976 & $9.69942 E-05$ & $0.003201819-0.00545520 .0056492$ \\
\hline & & & 0.03 & 10.376 & 0.976 & 9.69942E-05 & $0.003201819-0.00568490 .0058789$ \\
\hline \multirow[t]{2}{*}{ Net Non-interest Margin } & 3.377 & 0.083 & -1.839 & 18 & 0.083 & -0.005401162 & $0.002937707-0.0104953-0.000307$ \\
\hline & & & -1.839 & 13.254 & 0.088 & -0.005401162 & $\begin{array}{ccc}0.002937707 & -0.010596 & -0.000206\end{array}$ \\
\hline \multirow[t]{2}{*}{ Provision to Earnings Asset } & 2.008 & 0.174 & -1.239 & 18 & 0.231 & -0.002884299 & $0.002327995-0.00692120 .0011526$ \\
\hline & & & -1.239 & 15.408 & 0.234 & -0.002884299 & $0.002327995-0.00655830 .00011897$ \\
\hline \multirow[t]{2}{*}{ Loan Ratio } & 0.179 & 0.678 & 2.035 & 18 & 0.057 & 0.062085399 & $0.03050495 \quad 0.00918790 .1149829$ \\
\hline & & & 2.035 & 17.762 & 0.057 & 0.062085399 & $0.03050495 \quad 0.00914950 .1150213$ \\
\hline \multirow[t]{2}{*}{ Loans to Deposits } & 4.237 & 0.054 & -0.894 & 18 & 0.383 & -1.160461707 & $1.298691045-3.41247461 .0915512$ \\
\hline & & & -0.894 & 9.071 & 0.395 & -1.160461707 & $1.298691045-3.53899985 \quad 1.218075$ \\
\hline \multirow[t]{2}{*}{ Cash to Asset } & 4.816 & 0.042 & -1.543 & 18 & 0.14 & -0.03968553 & $0.025727351-0.08429840 .0049273$ \\
\hline & & & $-1,543$ & 14.89 & 0.144 & -0.03968553 & $0.025727351-0.08480870 .0054377$ \\
\hline \multirow[t]{2}{*}{ Cash to Deposits } & 6.91 & 0.017 & -1.484 & 18 & 0.155 & -0.053078456 & $0.035758837-0.11508660 .0089296$ \\
\hline & & & -1.484 & 13.379 & 0.161 & -0.053078456 & $\begin{array}{llll}0.035758837 & -0.116268 & 0.0101111\end{array}$ \\
\hline \multirow[t]{2}{*}{ Deposit to Assets } & 4.303 & 0.053 & -0.473 & 18 & 0.642 & -0.0235919 & $\begin{array}{lll}0.049924969 & -0.110165 & 0.0629812\end{array}$ \\
\hline & & & -0.473 & 12,125 & 0.645 & -0.0235919 & $\begin{array}{llll}0.049924969 & -0.1124962 & 0.0653124\end{array}$ \\
\hline \multirow[t]{2}{*}{ Equity Multiplier } & 1.099 & 0.308 & 0.077 & 18 & 0.94 & 0.048732151 & $0.636350744-1.0547405 \quad 1.1522048$ \\
\hline & & & 0.077 & 14.621 & 0.94 & 0.048732151 & $0.636350744-1.06872591 .1661902$ \\
\hline \multirow[t]{2}{*}{ Equity to Deposits } & 2.998 & 0.1 & 0.738 & 18 & 0.47 & 0.039397534 & $0.053411955-0.05322220 .1320173$ \\
\hline & & & 0.738 & 9.57 & 0.478 & 0.039397534 & $0.053411955-0.05785250 .1366476$ \\
\hline \multirow[t]{2}{*}{ Toatl Liability to Equity } & 1.099 & 0.308 & 0.077 & 18 & 0.94 & 0.048719744 & $0.636351754-1.0547547 \quad 1.1521942$ \\
\hline & & & 0.077 & 14.621 & 0.94 & 0.048719744 & $0.636351754-1.06874011 .16661796$ \\
\hline \multicolumn{8}{|l|}{ Total liability to Shareholder } \\
\hline \multirow[t]{2}{*}{ Capital } & 1.099 & 0.308 & 0.077 & 18 & 0.94 & 0.048719744 & $0.636351754-1.0547547 \quad 1.1521942$ \\
\hline & & & 0.077 & 14.621 & 0.94 & 0.048719744 & $0.636351754-1.0687401 \quad 1.1661796$ \\
\hline \multirow[t]{2}{*}{ Return Earning to Total Assets } & 0.036 & 0.852 & $-1,091$ & 18 & 0.29 & -0.014013786 & $0.012841536-0.03628180 .0082543$ \\
\hline & & & $-1,091$ & 17.886 & 0.29 & -0.014013786 & $0.012841536-0.0362895 \quad 0.0082619$ \\
\hline
\end{tabular}




\section{$\begin{array}{rr}\text { Macrothink } & \text { International Journal of Accounting and Financial Reporting } \\ \text { Instrite } & \text { IST }\end{array}$}

\section{Copyright Disclaimer}

Copyright for this article is retained by the author(s), with first publication rights granted to the journal.

This is an open-access article distributed under the terms and conditions of the Creative Commons Attribution license (http://creativecommons.org/licenses/by/4.0/) 